\title{
Internal Locus of Control as a Driving Factor of Early Detaction Behavior of Servical Cancer by Inspection Visual of Acetic Acid Method
}

\author{
Abdul Muhith ${ }^{1 *}$, Eko Winarti ${ }^{2}$, S. S. Idola Perdana ${ }^{1}$, Sri Haryuni ${ }^{1}$, Kun Ika Nur Rahayu $^{1}$, Anwar Mallongi ${ }^{3}$ \\ ${ }^{1}$ Department of Nursing Science, University of Nahdlatul Ulama Surabaya, Surabaya, Indonesia; ${ }^{2}$ Study Program of Nursing, \\ Faculty of Health Sciences, University of Kediri (UNIK), Kediri, East Java, Indonesia; ${ }^{3}$ Department of Environmental Health, \\ Faculty of Public Health, Universitas Hasanudin Makasar, Indonesia
}

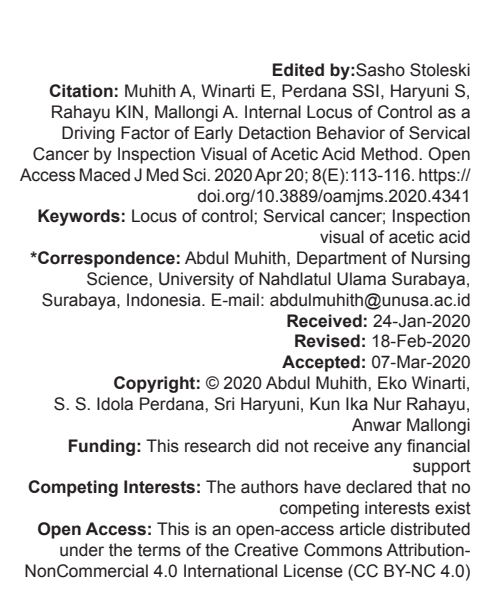

\section{Introduction}

Cervical cancer is one of the main reproductive health problems and is a cause of death to women in the world, especially in developing countries like Indonesia [1]. This disease is also called "hidden or silent cancer" because usually, patients have no symptoms [2].

Cervical cancer is the most common malignancy to women, ranks fourth in the world and is a major global health challenge. About $90 \%$ of 270,000 deaths from cervical cancer in 2015 occurred in low- and middle-income countries, where the incidence of death was 18 times higher than in developed countries. In 2018, an estimated 569,847 new cases of cervical cancer were diagnosed, and 311,365 deaths occurred worldwide due to this malignancy [3]. In Indonesia, around 13,762 women are diagnosed with cervical cancer each year and 7493 die. Cervical cancer in Indonesia ranks second after breast cancer. East and Central Java have the highest cervical cancer cases in Indonesia. East Java is the region with the first rank of cervical cancer cases in Indonesia [4].
Several epidemiological studies reveal the role of various risk factors in the incidence of cervical cancer. These risk factors include sexually transmitted infections (STIs), reproductive and sexual factors, behavioral factors, nutritional and dietary factors, inflammatory disease, and host factors. STIs include human papillomavirus (HPV), chlamydia trachomatis, human immunodeficiency virus, and herpes simplex virus. HPV is the most important etiology in cervical cancer. Over the past few years, HPV testing (as a screening method) and vaccination were introduced for the prevention of cervical cancer. Reproductive and sexual factors include sexual partners, parity, and oral contraceptives. Behavioral factors include smoking and obesity [5].

In Indonesia, in general, cervical cancer patients who go to the hospital are in an advanced stage, namely: Stage IA and IIA accounted for $28.6 \%$, and Stages IIB to IVB accounted for $66.4 \%$ [6]. For this reason, early detection is of necessity so that it can be detected early if there are wounds/lesions of pre-cancer, and immediate intervention can be carried out quickly and appropriately. One way to do early detection is by inspection visual 
of acetic acid (IVA). This examination is a cheap and effective initial examination to detect cervical cancer.

The coverage of early detection of cervical cancer by the IVA method in Indonesia is still low $(2.45 \%)$. In Kediri City, the implementation of early detection of cervical cancer by the IVA method is still low $(<1 \%$ target of the Kediri City Health Service set at $10 \%)$. This certainly requires more effort to reach the target [6]. The low participation of women of childbearing age in the early detection of cervical cancer using the IVA method can be caused by various factors. Some studies mention that individual factors and environmental factors greatly influence the behavior of women to make early detection of cervical cancer using the IVA method. This is in accordance with the health biopsychosocial model, in which biological, psychological, and social aspects contribute greatly to one's health status [7].

Psychological and social learning theories referring to the extent to which individuals perceive control over their lives and the environment are called locus of control [8]. Locus of control can be categorized into two types, namely, internal locus of control, assuming the belief that within him is stored a great potential for self-determination. An external locus of control is a perspective in which all results, good or bad, are beyond their control [9].

Locus of control is a learning theory on psychological and social aspects. Psychological and social aspects are factors that influence a woman's behavior to conduct early detection of cervical cancer using the IVA method. Research on the locus of control on early detection of cervical cancer using the IVA method has never been done, so it is necessary to do research on the relationship of locus of control and the behavior of early detection of cervical cancer IVA method.

The purpose of the study was to find out the relationship between locus of control and the behavior of early detection of cervical cancer by the IVA method.

\section{Methods}

This research is a cross-sectional study. This research was conducted in all community health centers (Puskesmas) in the Work Area of the City of Kediri, with a total of nine community health centers spread across three sub-districts of Kediri, namely, Kecamatan Kota, Kecamatan Pesantren, and Kecamatan Mojoroto. The population used in the study was all women aged $20-50$ years subjected to IVA. The sample of the study was 393 respondents. The sampling technique used is multi-stage random sampling. The variables of the study were the locus of control as the independent variable and the behavior of early detection of cervical cancer by the IVA method as the dependent variable. There were two types of instruments used in the study, the first was the instrument for locus of control in the form of a questionnaire already tested for its validity and reliability, and the second was an instrument for early detection of cervical cancer by IVA method using observation sheets. The data analysis used SPSS software. The data analysis technique used in the study was the correlation technique, using the Spearman rho test with a value of $\alpha=0.05$

\section{Results}

The research respondents used were 393 respondents. The respondents were chosen randomly from women aged from 20 to 50 years. At the time of the study, all the respondents ( $100 \%)$ were aged $\geq 20$ years, totaling 393 respondents. Almost all the respondents (96.4\%) did not have a history of cervical cancer, which were 379 respondents. Most respondents (51.9\%) had never taken IVA, totaling 204 respondents. Almost half of the respondents (49.1\%) had secondary education (high school equivalent), totaling 193 respondents. Most respondents (71\%) work as housewives, totaling 279 respondents. Most respondents (67.9\%) had an internal locus of control, totaling 267 respondents. Most of the respondents (52.2\%) did not implement IVA, totaling 205 respondents.

The correlation between the locus of control and the early detection of cervical cancer by the IVA method is shown in Table 1.

Table 1: The correlation between the locus of control and the behavior of early detection of cervical cancer by the IVA method

\begin{tabular}{|c|c|c|c|}
\hline & & $\begin{array}{l}\text { Locus of } \\
\text { control }\end{array}$ & $\begin{array}{l}\text { Behavior of early } \\
\text { detection of cervical } \\
\text { cancer by IVA method }\end{array}$ \\
\hline \multicolumn{4}{|l|}{ Spearman's rho } \\
\hline \multirow[t]{2}{*}{ Locus of control } & $\begin{array}{l}\text { Correlation coefficient } \\
\text { Sig. (two-tailed) }\end{array}$ & 1.000 & $\begin{array}{l}0.603^{\star \star} \\
0.000\end{array}$ \\
\hline & $\mathrm{n}$ & 393 & 393 \\
\hline \multirow{2}{*}{$\begin{array}{l}\text { Behavior of early } \\
\text { detection of cervical } \\
\text { cancer by IVA method }\end{array}$} & Correlation coefficient & $0.603^{\star *}$ & 1.000 \\
\hline & Sig. (two-tailed) & $\begin{array}{l}0.000 \\
393\end{array}$ & 393 \\
\hline
\end{tabular}

Based on Table 1, the result of the Spearman's test, the results show that the significance value (Sig. [two-tailed]) is 0.000 , while the value of $\alpha=0.05$. Because the significance value $(0.000)$ is smaller than $\alpha=0.05$ ) value, it means there was a significant (meaningful) correlation between the locus of control variable and that of the early detection behavior of cervical cancer by IVA method.

Based on Table 1, the results show that the correlation coefficient is 0.603 . This means that the level of strength of the correlation between the locus of control variable and that of the variable behavior of 
early detection of cervical cancer by the IVA method is 0.603 or strong. The correlation coefficient value in Table 1 is positive, which is 0.603 . This means that the correlation between the two variables is unidirectional; thus, it can be interpreted that the better the locus of control, the better the behavior of early detection of cervical cancer by the IVA method.

IVA is an effective and inexpensive screening test that can be combined with simple treatment procedures for early cervical lesions which are provided by trained health workers [10]. Early detection by IVA is able to correctly identify precancerous lesions and cervical cancer [11]. IVA provides excellent results, especially for ectocervix, at minimum costs. Therefore, it is very suitable to be used as cervical cancer screening in developing countries like Indonesia [12].

In several studies, it was mentioned that individual factors and environmental factors influence the behavior of women to make early detection of cervical cancer using the IVA method. This was in accordance with the health biopsychosocial model, in which biological, psychological, and social aspects contribute greatly to one's health status [7]. Psychological and social aspects also becoming behavioral factors for early detection of cervical cancer using the IVA method are locus of control.

Locus of control is a type of personality variable perceived as an individual's belief in his ability to control his destiny [13]. Internal locus of control is a state in which individuals belief that if they work hard then they will succeed, and believe if people fail due to lack of ability and or motivation [14]. External locus of control is a state in which an individual believes that the fate, luck, opportunity, or behavior of people determines what will happen to them [15].

Based on the research, the finding was that the majority of respondents $(67.9 \%)$ had an internal locus of control, and the number was 267 respondents. The respondents with an internal locus of control had confidence that if they do not want to develop cervical cancer, they must work hard to prevent cervical cancer, one way of which is through early detection of cervical cancer by the IVA method. They also believe that people affected by cervical cancer are due to a lack of ability and or motivation to do early detection of cervical cancer.

However, even though $67.9 \%$ of respondents had an internal locus of control, the majority of the respondents $(52.2 \%)$ did not implement IVA, and the number was 205 respondents. This might be due to the level of education of the respondent or occupational factors. Most of the respondents had a high school education and jobs as housewives. This was likely to cause their poor understanding of the importance of examining the early detection of cervical cancer.

Almost all the respondents $(96.4 \%)$ did not have a history of cervical cancer, totaling 379 respondents.
This also caused most respondents not to implement IVA even though most of them had an internal locus of control. Compared with other types of cancer, family history of cervical cancer had an influence on the implementation of cervical cancer screening [16]. This also happened to respondents; only a few had a history of cervical cancer, so most did not carry out IVA. Despite not having a history of cervical cancer, every woman is targeted to screen for cervical cancer even though they really feel very healthy [17], [18], [19].

\section{Conclusion}

The conclusion of the study was that there was a significant correlation between the locus of control variable and that of the early detection of cervical cancer by IVA method. The higher the internal locus of control possessed by a woman, the better the behavior of early detection of cervical cancer by the IVA method.

\section{References}

1. Muhith A, Sulistyorini L, Sutarti T, Mallongi A, Mujib H. Structural equation modeling: Community empowermenton health status and pregnant women nutritional. J Eng Appl Sci. 2019;14(7):2385-92. https://doi.org/10.36478/jeasci.2019.2385.2392

2. Seng LM, Rosman AN, Khan A, Haris NM, Mustapha NA, Husaini NS, et al. Awareness of cervical cancer among women in Malaysia. Int J Health Sci (Qassim). 2018;12(4):42-8. PMid:30022903

3. Cohen PA, Jhingran A, Oaknin A, Denny L. Cervical cancer Lancet. 2019;393(10167):169-82. https://doi.org/10.1016/ s0140-6736(18)32470-x

PMid:30638582

4. Winarti E, Santoso B, Hargono R. Trigger, self efficacy and motivation in the implementation of cervical cancer screening. Health Notions. 2018;2(4):494-9.

5. Momenimovahed Z, Salehiniya $H$. Incidence, mortality and risk factors of cervical cancer in the world. Biomed Res Ther 2017;4(12):1795-811. https://doi.org/10.15419/bmrat.v4i12.386

6. Tatik S, Muhith A, Anwar M, Himawan SM, Lilik D. Analysis of educational factors, interest and motivation towards the behavior of early detection of cancer cerviks in women of fertile age in the upt health Center Kembangbahu. Indian J Public Health Res Dev. 2018;9(12):1371-5. https://doi. org/10.5958/0976-5506.2018.02044.2

7. Saptowati D, Mudigdo A, Murti B. biopsychosocial determinants of visual inspection acetic-acid test uptake in Sragen, Central Java. J Matern Child Health. 2017;3(3):197-206. https://doi. org/10.26911/thejmch.2018.03.03.04

8. Peters K. Impact of locus of control expectancy on level of wellbeing impact of locus of control expectancy on level of wellbeing. Rev Eur Stud. 2012;4:124-37. https://doi.org/10.5539/ res.v4n2p124

9. Wang L. Internal-external locus of control scale. In: Encyclopedia of Personality and Individual Differences. Cham: Springer 
International Publishing; 2017. p. 1-4.

10. Poli UR, Bidinger PD, Gowrishankar S. Visual inspection with acetic acid (VIA) screening program: 7 years experience in early detection of cervical cancer and pre-cancers in rural South India. Indian J Community Med. 2015;40(3):203-7. https://doi. org/10.4103/0970-0218.158873

PMid:26170547

11. Qiao L, Li B, Long M, Wang X, Wang A, Zhang G. Accuracy of visual inspection with acetic acid and with lugol's iodine for cervical cancer screening: Meta-analysis. J Obstet Gynaecol Res. 2015;41(9):1313-25. https://doi.org/10.1111/jog.12732 PMid:26014371

12. Utami TW, Nuranna L, Mahathir M, Peters AA, Fleuren GJ, Osse $M$, et al. Visual inspection of acetic acid (VIA) as a promising standard for cervical cancer screening. Indones $J$ Obstet Gynaecol. 2014;2(4):216-9. https://doi.org/10.32771/ inajog.v2i4.411

13. Fahim H, Ghahramanlou F, Fooladian A, Zohoorian Z. The relationship between locus of control (internal external) and happiness in pre-elementary teachers in Iran. Procedia Soc Behav Sci. 2012;46:4169-73. https://doi.org/10.1016/j. sbspro.2012.06.220

14. Muhith A, fardiansyah A, Saputra MH, Nurmiyati N. Analysis of causes impacts of early marriage on madurese sumenep East Java Indonesia. Indian J Public Health Res Dev. 2018;9(8):4126. https://doi.org/10.5958/0976-5506.2018.00944.0

15. Pourhoseinzadeh $M$, Gheibizadeh $M$, Moradikalboland $M$.
The relationship between health locus of control and health behaviors in emergency medicine personnel. Int J Community Based Nurs Midwifery. 2017;5(4):397-407. PMid:29043285

16. Bellinger JD, Brandt HM, Hardin JW, Bynum SA, Sharpe PA, Jackson $D$. The role of family history of cancer on cervical cancer screening behavior in a population-based survey of women in the Southeastern United States. Womens Health Issues. 2013;23(4):e197-204. https://doi.org/10.1016/j.whi.2013.03.003 PMid:23722075

17. World Health Organization. Comprehensive Cervical Cancer Prevention and Control: A Healthier Future for Girls and Women. Geneva: World Health Organization; 2013.

18. Mallongi A, Abdullah M, Mattangang A, Pulubuhu DA, Arsyad M, Muhith A, et al. Spatial Pattern and Social Evironmental Risk Factors of Leprosy Occurrence in Barru, Indonesia. Indonesia: Tahir and Mattangang, Apollo and Pulubuhu, Dwia Aries Tina and Arsyad, Muhammad and Muhith, Abdul and Sutarti, Tatik and, Herawati and Rachmat, Muhammad, Spatial Pattern and Social Evironmental Risk Factors of Leprosy Occurrence in Barru; 2019. Available from: https://www.ssrn.com/abstract $=3367052$ [Last accessed on 2019 Apr 04].

19. Muhith A, Mallongi A, Selomo M, Daud A, Rahman SA, Mattangang $A$, et al. The spatial pattern and risk factors of leprosy occurrence in Barru Indonesia. Indian J Public Health Res Dev. 2018;9(8):1489-94. https://doi. org/10.5958/0976-5506.2018.00943.9 